\section{A checklist of malacofauna of the Vellar Estuarine Mangroves, India}

\section{K. Kesavan ${ }^{1}$, C. Palpandi ${ }^{2}$ \& A. Shanmugam ${ }^{2}$ \\ 1,2 Centre of Advanced Study in Marine Biology, Annamalai University, Parangipettai, Tamil Nadu 608502, India \\ Email: ${ }^{1}$ k7til@yahoo.co.in}

Mangroves provide ideal conditions for high productivity of gastropods, which, in turn, serve as food, particularly the veliger larvae for numerous animals. Because of their predatory nature, gastropods play an important role in maintaining the function and productivity of mangroves through "cleansing" root systems by removing the encrusting fauna like barnacles. These snails also serve as intermediate host for many trematode parasites. Based on the structure of molluscan assemblages , pollution induced damage in mangrove forests can be evaluated. Hence, this study has been made to update the inventory of molluscs in Vellar Estuary.

The river Vellar flowing on the southeastern coast of India originates in the Servarayan hills of Salem District (Tamil Nadu, southern India). After meandering $480 \mathrm{kms}$, it discharges water into the Bay of Bengal at Parangipettai (formerly known as Porto Novo). The Vellar estuary $\left(11^{\circ} 29^{\prime} \mathrm{N}\right.$ $\& 79^{\circ} 46^{\prime} \mathrm{E}$ ) is perennially open.

For quantitative analysis, the molluscs were hand picked in a transect of known area or a quadrate of known size. Foulers like mussels and oysters were collected by scraping with knife or spatula. The infaunal bivalves were collected by digging the substratum. The arboreal forms were hand picked from the stems, roots and other parts of the mangrove trees vertically at every $25 \mathrm{~cm}$ interval (Alfred 1997).

The macrobenthic molluscs of the estuary may be broadly grouped under three categories (1) arboreal, those live attached to stem and roots of mangrove vegetation (2) epifauna, lying on the mud of the intertidal area (3) infauna, burying themselves in the substratum. Some gastropods have habitat overlap.

Out of the 13 species (10 species of gastropods and 3 species of bivalves) observed in the Vellar Estuary mangroves, 6 species were arboreal and the remaining 4 species of gastropods crawl on the muddy substratum. There are

Date of online publication 26 July 2009

ISSN 0974-7907 (online) | 0974-7893 (print)

Editor: M.B. Raghunathan

Manuscript details:

Ms \# 01912

Received 24 December 2007

Final received 04 May 2009

Finally accepted 16 June 2009

Citation: Kesavan, K., C. Palpandi \& A. Shanmugam (2009). A checklist of malacofauna of the Vellar Estuarine Mangroves, India. Journal of Threatened Taxa 1(7): 382-384.

Copyright: (C K. Kesavan, C. Palpandi \& A. Shanmugam 2009. Creative Commons Attribution 3.0 Unported License. JoTT allows unrestricted use of this article in any medium for non-profit purposes, reproduction and distribution by providing adequate credit to the authors and the source of publication. exceptions i.e., $N$. violacea is usually found attached to mangrove trees at the edge of the water which are subject to tidal action In the absence of mangrove vegetation, it attaches on other structures squeeze into the gaps of the bricks, cracks and crevices of concrete / brick structures lining the banks in addition to solid materials lying in the muddy substratum. About 100 species of molluscs are known to occur in the mangrove areas of Indian subcontinent (Dey 2006), 11 from Godavari estuary (Ganapati 1959), 9 from Krishna estuary (Radhakrishna 1975), 20 from Mahanadi estuary (Roa 1975), 6 from Palk Bay \& Gulf of Mannar (Pillai \& Appukuttan 1980), 10 from Pichavaram Mangroves (Kasinathan \& Shanmugam, 1985). Hundred species have been reported from mangroves of Andaman and Nicobar islands (Das \& Roy 1989). In the present study 13 species of molluscs were recorded in mangroves of Vellar Estuary Mangroves.

\section{A systematic list of species occurring in the Vellar Estuarine Mangroves}

Phylum: Mollusca

Class: Gastropoda

Sub Class: Prosobranchia

Order: Archaeogastropoda

Family: Neritidae

Genus: Neritina (Dostia)

Neritina violacea (Gmelin)

Order: Mesogastropoda

Family: Littorinidae

Genus: Littorina

Littorina melanostoma (Gray)

Littorina scabra (Linnaeus)

Family: Assiminidae

Genus: Assiminea

Assiminea nitida (Pease, 1865)

Family: Potamididae

Genus: Cerithidea

Cerithidea cingulata (Gmelin)

Cerithidea obtusa Lamarck

Genus: Telescopium

Telescopium telescopium (Linnaeus)

Subclass: Pulmonata

Order: Bassommatophora

Family: Ellobiidae

Genus: Ellobium

Ellobium aurisjudae (Linnaeus)

Genus: Cassidula

Cassidula nucleus (Gmelin)

Genus: Melampus

Melampus ceylonicus (Petit)

Order: Mytiloida

Family: Mytilidae

Genus: Modiolus

Modiolus metcalfei (Hanley)

Genus: Perna

Perna viridis (Linnaeus, 1758) 


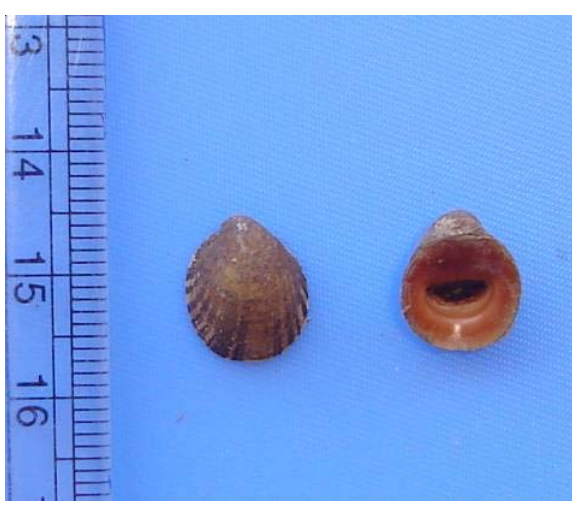

Neritina (Dostia) violacea

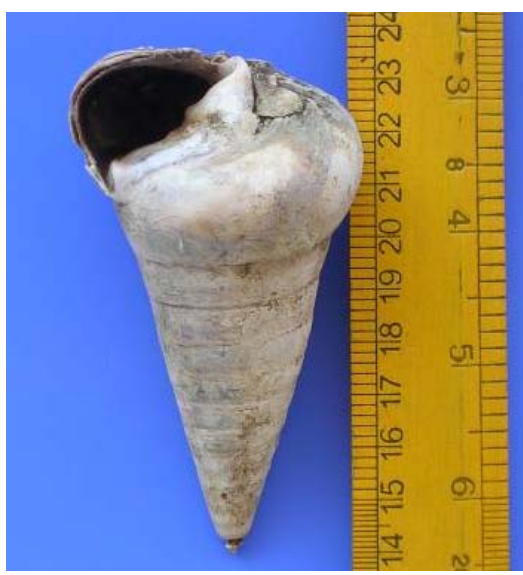

Telescopium telescopium

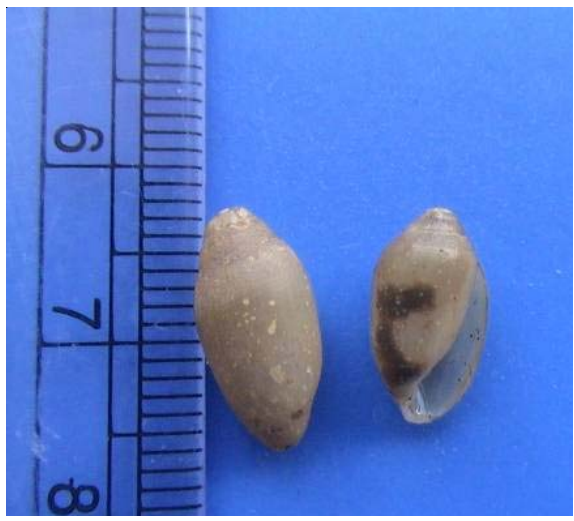

Ellobium auris-judae

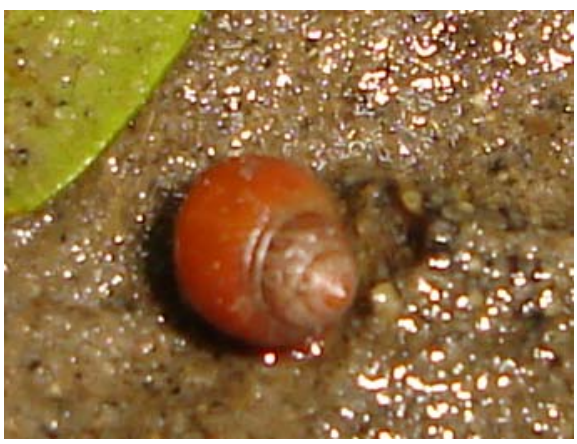

Assiminea nitida

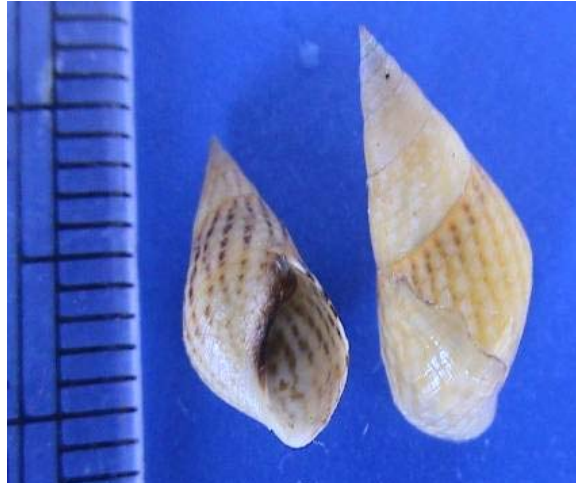

Littorina (Palustorina) melanostoma

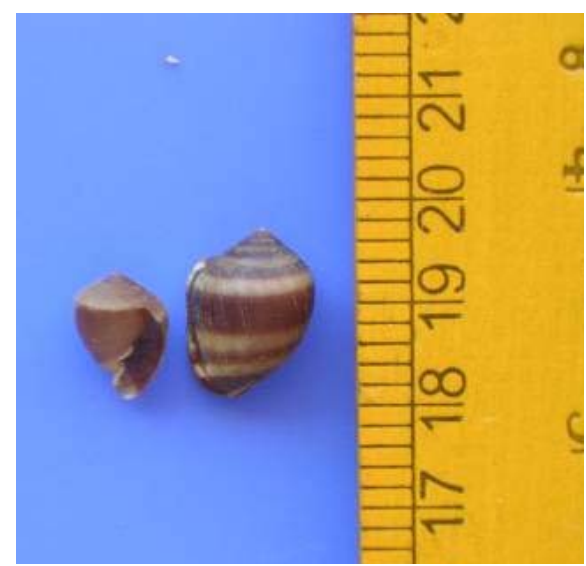

Cassidula nucleus

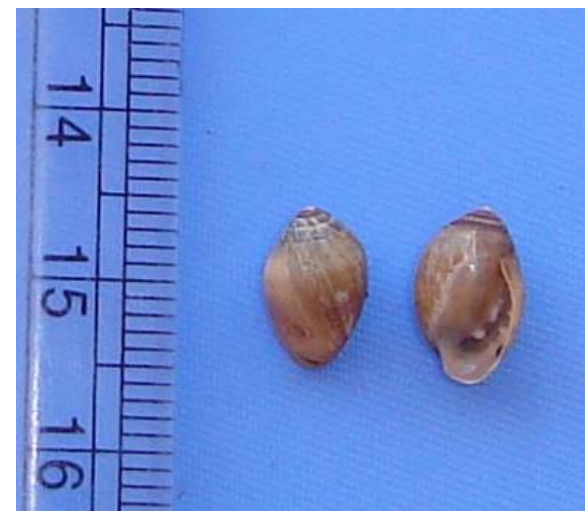

Melampus ceylonicus

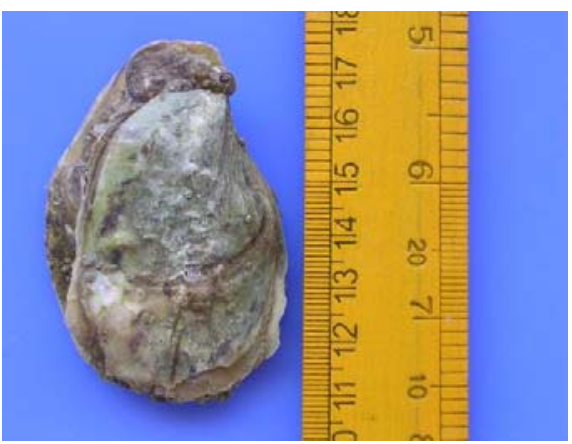

Crassostrea madrasensis

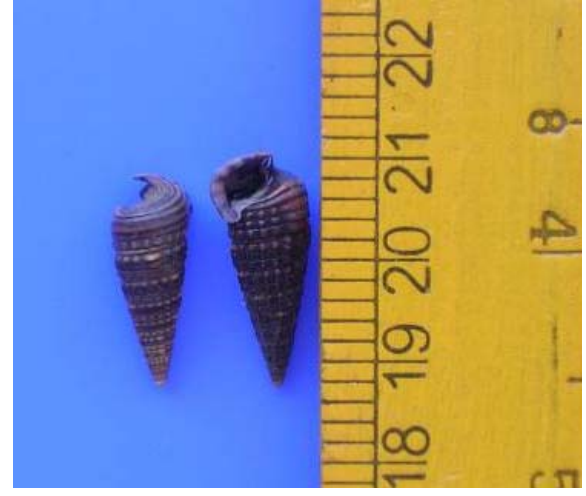

Cerithidea cingulata

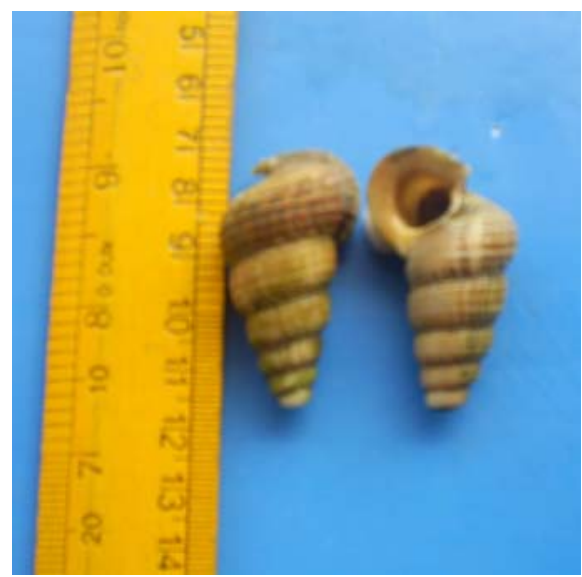

Cerithidea obtusa

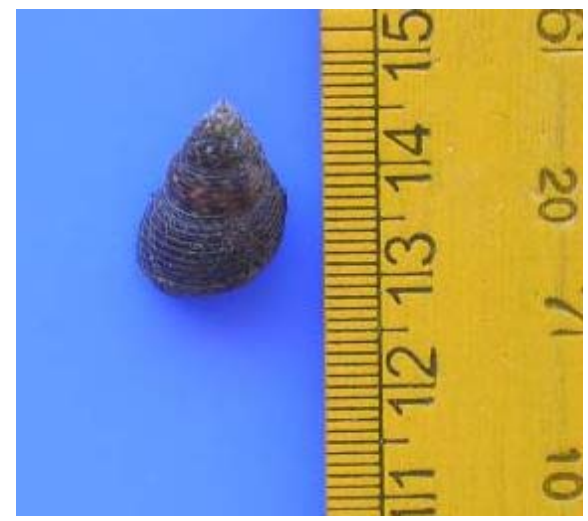

Littorina (Littorinopsis) scabra

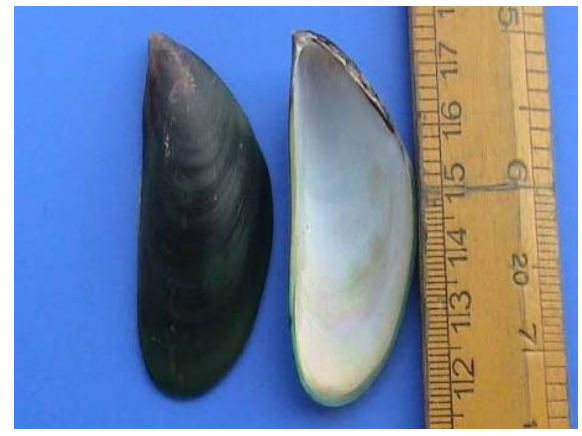

Perna viridis 


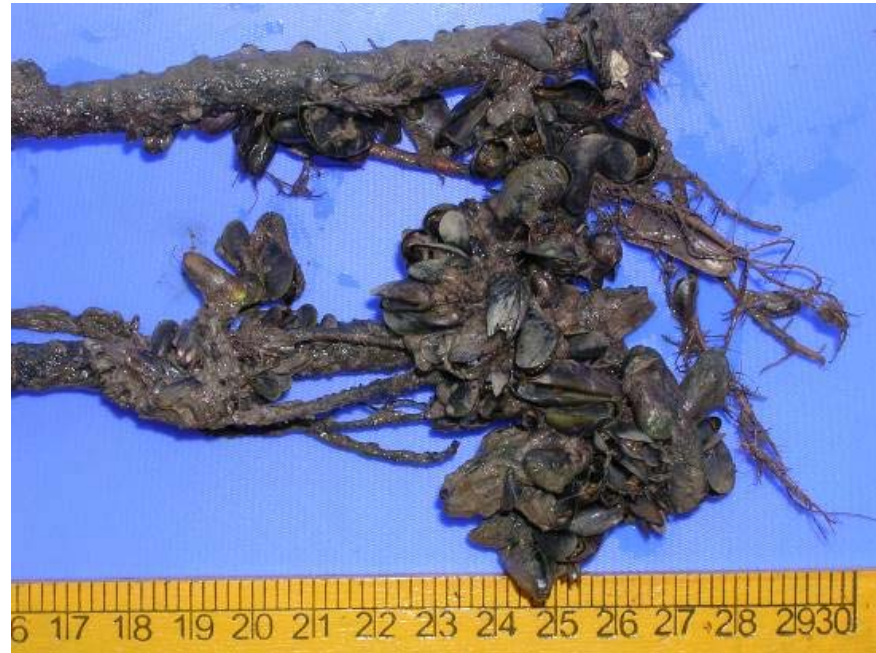

Modiolus metcalfei

Family: Ostreidae

Genus: Crassostrea

Crassostrea madrasensis (Preston)

\section{References}

Alfred, J.B., R.K. Varshney \& A.K. Ghosh (Eds.) (1997). An Assessment Manual for Faunal Biodiversity in South Asia. SACEP/NORAD publication series on Biodiversity in South Asia No. 1: 181pp.

Das, A.K. \& M.K.D. Roy (1989). A general account of the mangrove fauna of Andaman and Nicobar islands. Conservation area series, Zoological Survey of India $4: 1-73$.

Dey, A. (2006). Handbook on Mangrove Associate Molluscs of Sunderbans. (Eds. Director, ZSI, Kolkata), 96pp.

Ganapati, P.N. \& M..L.V. Rao (1959). Incidence of marine borers in the mangrove of Godavari estuary. Current Science 28(8):332.

Kasinathan, R. \& A. Shanmugam (1985). Molluscan fauna of Pichavaram mangroves, Tamil Nadu. Proceedings of the Nat. Sym. Biol. Util. Cons. mangroves, Kolhapur, Distribution, India, pp. 438-443.

Pillai, C.S.G. \& K.K. Appukuttan (1980). Distribution of molluses in and around coral reefs of the south eastern coast in India. Journal of the Bombay Natural Hisotry Society 77(1): 26-48.

Radhakrishna,Y. \& Janakiram (1975). The mangrove molluscs of Gadavari and Krishna estuary, pp. 177-184. In: Natarajan, R. (ed.). Resent Researches in Estuarine Biology. Hisdustan publishing corporation (L), Delhi, India.

Rao, N.V.S. \& H.P. Mookherjee (1975). On the collection of molluca from Mahanadi estuary, Orissa, pp. 165-176. In: In: Natarajan, R. (ed.). Resarches in Estuarine Biology. Hisdustan publishing corporation (L), Delhi, India. 